\title{
EFFECT OF SUPPLEMENTAL MANNAN OLIGOSACCHARIDE TO RABBIT DIETS ON PRODUCTIVE AND REPRODUCTIVE PERFORMANCE OF DOES DURING SUMMER SEASON IN EGYPT
}

\author{
W.A. Morsy ${ }^{*}$ and A.I. Abd El-Lateif \\ Animal Production Research Institute, Agricultural Research Center, Ministry of Agriculture, \\ Dokki, Cairo, Egypt.
}

"Corresponding author: wawad74@yahoo.com

\section{SUMMARY}

The objective of this study was to evaluate the effects of dietary mannan oligosaccharide (Bio-
Mos) supplementation on reproductive, productive performance and milk production of APRI
line rabbit does under high ambient temperature. A total of 40 APRI line rabbit does, 8-9 months old, were divided into four experimental treatments (10 each). Rabbit does were fed ad libitum the basal diet supplemented without (control), with $0.5,1$ or $1.5 \mathrm{~g}$ mannan oligosaccharide (Bio-Mos) $/ \mathrm{kg}$ diet. Animals were provided with water freely. The average daily temperature and relative humidity inside the rabbitry were $31.6 \pm 3.8{ }^{\circ} \mathrm{C}$ and $77.5 \pm 4.8 \%$, respectively. Under heat stress conditions, does weight gain at gestation significantly increased $(\mathrm{P}<0.001)$ with increasing dietary MOS supplementation. Pregnant rabbit does given diet containing $1.5 \mathrm{~g}$ MOS $/ \mathrm{kg}$ diet showed the highest weight gain than those fed other dietary MOS levels during the pregnancy period. Daily feed intake of pregnant and lactating rabbit does increased $(\mathrm{P}<0.05)$ with increasing dietary MOS level, where rabbit does fed diet containing $1.5 \mathrm{~g}$ MOS $/ \mathrm{kg}$ diet recorded the highest values. The feed conversion ratio was significantly improved $(\mathrm{P}<0.001)$ with rabbit does fed diets containing different MOS level $(0.5,1.0$ and $1.5 \mathrm{~g})$ during lactation period. The mortality rate of the pups during the lactation period was higher in the control diet compared to diets with $0.5,1.0$ and $1.5 \mathrm{~g}$ MOS (32.11\% vs. 25.82, 18.37 and $17.77 \%$; $\mathrm{P}<0.01$, respectively), which could be due to lower milk yield of rabbit does fed unsupplemented diet. Rabbit does fed 1.0 and $1.5 \mathrm{~g} \mathrm{MOS} / \mathrm{kg}$ diet recorded the highest values of letters weights, during the first three weeks. The same trend was obtained at weaning. Rabbit does fed $1.5 \mathrm{~g} \mathrm{MOS} / \mathrm{kg}$ diet recorded the highest net revenue, followed by those fed $1.0 \mathrm{~g}$ MOS/kg diet. It could be concluded that supplementing MOS in rabbit does diet significantly improve the overall productive and reproductive performance of rabbits does during pregnancy and lactation periods, in addition to depressing the mortality of pups under high ambient temperature during summer season in Egypt. Therefore, it could be recommended providing rabbit does diet with MOS up to $1.5 \mathrm{~g} / \mathrm{kg}$ diet is advisable in hot climates, Egypt.

Keywords: Rabbit, Mannan oligosaccharide, Heat stress, Reproductive performance.

\section{INTRODUCTION}

Climatic heat is the major factor restricting animal productivity. Rabbits are very sensitive to high environmental temperature, where the dense fur and lack of sweat glands make heat loss very difficult above the zone of thermal neutrality. Exposure of adult female rabbits to severe heat stress $\left(30-31{ }^{\circ} \mathrm{C}\right)$ adversely affects their growth and reproductive rates (Marai et al., 2001). In female rabbits, conception rate, embryonic development, litter size, litter weight and milk production decrease, while age at puberty and pre- and post-weaning mortality increase by exposure to heat stress (Habeeb et al., 1999). The drastic changes that occur in rabbits' biological functions are depression in feed intake, feed efficiency and feed utilization, disturbances in metabolism of water, protein, energy and mineral balances, enzymatic reactions, hormonal secretions and blood metabolites (Marai et al., 2002).

The concept of prebiotics in feed is fairly recent. Some of the prebiotics, which are currently used in animal feed, are Mannan-oligosaccharides (MOS). Mannan-oligosaccharides are mainly obtained from cell walls of Saccharomyces cerivisae and interferes with the colonization of the pathogens. Cell surface carbohydrates are primarily responsible for cell recognition. Bacteria have lectins (glycoprotein) on the cell surface that recognize specific sugars and allow the cell to attach to that sugar. Binding of Salmonella, E.coli and Colostridia sp. is shown to be mediated by a mannose specific lectin (receptor) like substance present on the bacterial cell surface. So, MOS exhibits an anti-adhesive 
effect where it binds to E. coli and Salmonella instead of binding to mucosal receptor and flushes them from the digestive tract, before the pathogens cause problems by anchoring themselves to the colon wall and improve intestinal health in other species (Spring et al., 2000; Fairchild et al., 2001; and Fernandez et al., 2003). Prebiotics can stand high pelletizing temperatures in the feed and also have a long shelf life (Huyghebaert, 2003 and Kembhavi, 2004).

Through improving gut health and the immune status MOS has shown to improve animal performance in broilers (Hooge, 2004a), turkeys (Hooge, 2004b), piglets (Miguel et al., 2002). Moreover, some studies have shown that MOS is as effective as other antimicrobial growth promoters (Savage et al., 1996; White, et al. 2002). While extensive information on MOS as a feed additive in available in different animal species, little researches have been conducted in rabbits. Morsy and Abd El-Lateif (2014) observed that supplementing of 1 or $1.5 \mathrm{gm}$ Bio-Mos/ $\mathrm{kg}$ diets of growing rabbits improve growth performance and reduce mortality.

The objective of this study was to evaluate the effects of dietary mannan oligosaccharide supplementation on productivity, reproductive performance and milk production of APRI line rabbit does under high ambient temperature.

\section{MATERIALS AND METHODS}

\section{Animals and experimental design:}

This study was carried out at Sakha Research Station, Animal Production Research Institute, Agriculture Research Center, Egypt. Forty multiparous lactating and non-lactating APRI line rabbit does (Egyptian line selected for litter weight at weaning according to Abou Khadiga et al. 2010) of about 8-9 months old with an average live body weight of $3023 \mathrm{~g}$, were used during a period from $1^{\text {st }}$ May 2016 to $30^{\text {th }}$ September 2016. Four experimental diets (10 does per diet) were used in this experiment. The basal diet composition (Table 1) was formulated to cover all essential nutrient requirements for rabbit does according to De Blas and Mateos (1998). Chemical analyses of the basal diet were carried out according to AOAC (2000) for crude protein, crude fiber, organic matter and ether extract. Rabbit does were fed ad libitum the basal diet without (control), with $0.5,1$ or $1.5 \mathrm{~g}$ mannan oligosaccharide (Bio-Mos) $/ \mathrm{kg}$ diet. Bio-Mos ${ }^{\circledR}$ (Alltech Inc., USA) is thermostable prebiotic containing mannan-oligosaccharides. Rabbit bucks were fed on control basal diet without any supplementation.

Sex ratio was included to give a female: male ratio 3: 1 throughout the experiment. A cycle of 16 hours of light and 8 hours of dark were applied. All does were kept under the same managerial conditions and were presented to the males 7 days after parturition. Ten days after mating, the does were tested for pregnancy by abdominal palpation. Non-pregnant rabbit does were remated directly after abdominal palpation. The experimental period included three reproductive cycles. Feed intake of rabbit does was recorded daily and the weight of litters was measured weekly. Suckling pups were allowed to eat the same diet of their mother at the 21 st day of lactation and were weaned at 30 days of age. During this period, solid feed intake of litters was recorded. Animals were housed in individual cages provided with feeders, automatic nipple drinkers and nest boxes. The rabbit house was open air with electric exhaust fans on the sides.

During the experimental period, ambient temperatures and relative humidity were measured in the rabbitry twice a day at $06: 00 \mathrm{~h}$ and 15:00 $\mathrm{h}$ and the temperature humidity index (THI) was calculated according to Marai et al. (2001):

$$
\mathrm{THI}=\mathrm{db}^{\circ} \mathrm{C}-\left[(0.31-0.31 \mathrm{RH}) \times\left(\mathrm{db}^{\circ} \mathrm{C}-14.4\right)\right]
$$

Where, $\mathrm{db}^{\circ} \mathrm{C}$ is dry bulb temperature in Celsius, and $\mathrm{RH}$ is the relative humidity as a percentage. The values obtained are then classified as follows: $<27.8=$ absence of heat stress, $27.8-28.9=$ moderate heat stress, 28.9-30.0 =severe heat stress and 30.0 and more =very severe heat stress (Marai et al., 2002).

To measure milk production, twenty lactating rabbit does (five per diet) were used. Rabbit does were separated from their pups after parturition and controlled suckling was applied. To prevent free nursing, does were placed in cages next to the nest box. Suckling took place once a day, (around 09.00) in the nest box, for a short period ( 8 to $10 \mathrm{~min}$.). Litter size of eight pups was kept constant throughout 
lactation and dead pups were replaced daily by pups of a similar weight and age provided from nurse does. Milk production was estimated daily from weight loss of rabbit does after suckling.

\section{Statistical analysis:}

Data were subjected to analysis of variance, using the general linear GLM procedures of SAS program (SAS, Institute, Inc., 1985). The application of the least significant ranges among the different treatment means was done according to Duncan (1955). The fertility rate was analysed by chi square test.

\section{RESULTS AND DISCUSSION}

\section{Temperature humidity index (THI):}

Means of ambient temperature, relative humidity and temperature humidity index (THI) inside the building were $31.6 \pm 3.8{ }^{\circ} \mathrm{C}, 77.5 \pm 4.8 \%$ and 30.4 , respectively, which indicate severe heat stress. According to Marai et al. (2002) there is very severe heat stress when THI is higher than 30.0.

\section{Does performance:}

The effect of experimental treatments on does performance is shown in Tables 2. It is clear that no significant differences in the live body weight of rabbit does at mating, partum and weaning, while at prepartum the live body weight of rabbit does significantly increased by increasing level of mannan oligoscharides $(\mathrm{MOS})$ in diet. Does weight gain at gestation significantly increased $(\mathrm{P}<0.001)$ by increasing dietary MOS supplementation ( 1 or $1.5 \mathrm{~g}$ ). Pregnant rabbit does given diet containing $1.5 \mathrm{~g}$ MOS $/ \mathrm{kg}$ diet showed the highest weight gain $(414.3 \mathrm{~g})$ than those fed other dietary MOS levels during the pregnancy period. The increase in the weight gain was due to the foetal growth as evident by almost similar body weight of rabbit does at the mating and partum (Parigi Bini et al., 1991). During the lactation period, the rabbit does irrespective of the experimental diets lost weight ranging from 87.1 to $110.7 \mathrm{~g}$, which was about $3.24 \%$ (as average) of their initial live body weight with low losses for rabbit does fed diets containing 1.0 or $1.5 \mathrm{~g} \mathrm{MOS} / \mathrm{kg}$ diet $(-90.7$ and $-87.1 \mathrm{~g}, \mathrm{P}<0.001$, respectively). The fat and energy balance are always negative in the lactating rabbit does (Xiccato, 1996). Daily feed intake of pregnant and lactating rabbit does increased $(\mathrm{P}<0.05)$ with increasing dietary MOS level, where rabbit does fed diet containing $1.5 \mathrm{~g} \mathrm{MOS} / \mathrm{kg}$ diet recorded the highest values, as compared with those fed control diet (151.3 and 216.8 vs. 131.2 and $191.8 \mathrm{~g}, \mathrm{P}<0.05$, respectively). Moreover, daily feed intake of pups in the period from 22 day of age until weaning increased linearly $(\mathrm{P}<0.001)$ as the level of MOS increased. Daily feed intake of lactating rabbit does increased by $44.77 \%$ (as average) as compared to that of pregnant rabbit does to compensate for the higher serve losses of body weight reverses.

The increase of feed intake during the lactation period compared to that of gestation phase was lower as compared to reported values of $80-90 \%$ in the literature (Lebas, 1984), this is probably due to higher ambient temperature during lactation period than that in the literature, resulting in the low feed intake by rabbit does (Prasad and Karim, 1998). Similar results were recorded by Morsy (2007) who found that daily feed intake of lactating rabbit does increased by $43.3 \%$ (as average) as compared to that of pregnant rabbit does.

\section{Milk production:}

The effect of experimental treatments on milk production is shown in Tables 3. The dietary MOS level had a significant effect on milk production; resulting in higher values for rabbit does fed diet with different supplemented levels of MOS than those fed the control diet. The milk yield increased $(\mathrm{P}<0.001)$ by 11.48 , 27.65 and $32.65 \%$ in rabbit does fed $0.5,1.0$ and $1.5 \mathrm{~g}$ MOS $/ \mathrm{kg}$ diet, respectively. The same trend was observed for milk production in relation to week of lactation, which was increased by increasing dietary MOS level throughout the lactation period. The feed efficiency of milk yield was improved $(\mathrm{P}<0.001)$ with supplementing MOS in the diet, where rabbit does fed 1.0 and $1.5 \mathrm{~g} \mathrm{MOS} / \mathrm{kg}$ diet recorded significantly the best values, as compared with those fed control diet $(0.577$ and 0.588 vs. $0.500 \mathrm{~g} / \mathrm{g}, \mathrm{P}<0.001$, respectively). The increase of milk yield may be due to the higher feed intake of rabbit does. In cows, Nour El-Din (2015) found that both Tonilisat yeast and Grow yeast products have favorable impacts on the productivity of dairy cows during early lactation.

\section{Letter performance:}

The effect of experimental treatments on letter performance is shown in Tables 4. Both size and weight of litters at the birth, 21 days and weaning (30 days) were affected by supplementing dietary MOS. The rabbit does fed diet containing high levels of MOS $(1.0$ and $1.5 \mathrm{~g} / \mathrm{kg})$ weaned more rabbits than those fed control diet (5.86 vs. 4.14; $\mathrm{P}<0.01$, respectively). The mortality rate of the pups during the lactation period 
was higher in the control diet compared to diets with $0.5,1.0$ and $1.5 \mathrm{~g}$ MOS (32.11\% vs. 25.82, 18.37 and $17.77 \%$; $\mathrm{P}<0.01$, respectively), which could be due to lower milk yield of rabbit does fed unsupplemented diet. The recorded high values for pre-weaning mortality rate in this study may be attributed to the direct effect of heat stress on the sensitive offspring, in addition to a reduction of milk production (Ayyat et al., 1995) due to the general depression of metabolic activity in such conditions (Shafie et al., 1984). Also, Mateos et al. (2010) indicated that supplementation of rabbit feeds with certain oligosaccharides and increases volatile fatty acids in the caecam of weanling rabbits, decreasing the caecal ammonia concentration. In addition, to stimulate the beneficial microflora of the gut, prebiotics may prevent the adhesion of pathogens to the mucosa and stimulate the immune response (Forchielli and Walker, 2005).

These results agreed with those of Fonseca et al. (2004) and Hooge et al. (2004a \& b) who reported that, the prebiotics reduced mortality with about $50 \%$ reduction compared with the control. In addition, Lactomannan as prebiotic may be had a role in reduced mortality rate by its role in modify $\mathrm{pH}$ of rabbit digestive tract promoting useful bacteria and inhibit the harmful ones (Pinheiro et al., 2004). It is, however, claimed that the mannan oligosaccharides from yeast cell wall work by providing specific binding sites (D-mannose) to enteric pathogens, thus reducing their chances to attach to the intestinal tract (Finucane et al., 1999). Since mannan oligosaccharides are not digested by the endogenous enzymes, they pass through the gut with the pathogens attached. There is also a "cleaning up" effect, i.e., they detach pathogens already attached to the gut (Newman, 1994). Furthermore, the possible antimicrobial activity of the prebiotics may be accounted for by their growth-promoting effects on bifidobacteria and lactobacilli. These bacteria can reinforce the barrier function of the intestinal mucosa, helping in the prevention of the attachment of pathogenic bacteria, essentially by crowding them out. These bacteria may also produce antimicrobial substances and stimulate antigen specific and nonspecific immune responses (Macfarlane and Cummings, 1999; and Roberfroid, 2000). On the other hand, the milk available per kit may also have a pronounced effect on the mortality of young rabbits (Rommers et al., 2001).

Until 3 weeks, the weight gain of young rabbit was affected by milk production, showing higher values of litter weight for diet supplemented with MOS than for unsupplemented diet. Moreover, rabbit does fed high levels of MOS recorded the highest values of letters weights, during the first three weeks. The same trend was obtained at weaning, where rabbit does fed diet containing 1.0 and $1.5 \mathrm{~g}$ MOS/ $\mathrm{kg}$ recorded the highest values of letters weights at weaning, as compares with those fed control diet (2494.3 and $2612.9 \mathrm{vs}$. $1444.3 \mathrm{~g}, \mathrm{P}<0.001$, repectively). Also, kit weight at birth was significantly increased by $17.67 \%$ for rabbit does feed 1.5 MOS g/ kg diet, as compared with those fed control diet. Moreover, rabbit does fed 1.0 and 1.5 $\mathrm{g}$ MOS/ kg diet recorded the highest values of kit weight at weaning, as compared with those fed control diet (433.8 and 446.5 vs. $349.5 \mathrm{~g}, \mathrm{P}<0.001$, respectively).

The dietary MOS level had a significant effect on the feed and milk conversion ratio during the first three weeks of lactation. The feed conversion ratio was significantly improved $(\mathrm{P}<0.001)$ with rabbit does fed diets containing different MOS level $(0.5,1.0$ and $1.5 \mathrm{~g})$ during lactation period. Also, milk index was significantly improved with increasing dietary MOS content; where rabbit does fed control diet recorded the lowest value, as compared with those fed diets containing different levels of MOS (3.370 vs. 3.603, 3.621 and 3.606, $\mathrm{P}<0.01$, respectively). An increase in the dietary MOS level increased $(\mathrm{P}<0.001)$ feed intake of pups in the last 9 days of the lactation period. Litters fed control diet seemed to compensate for the lower amount of milk available to them with a lower feed intake. Also, the feed conversion ratio was better $(\mathrm{P}<0.01)$ for the high MOS level $(1.0$ and $1.5 \mathrm{~g})$ than control group, during the last 9 days of lactating period (3.940 and 3.959 vs. $6.054 \mathrm{~g} / \mathrm{g}, \mathrm{P}<0.01$, respectively). During this stage, the differences were more evident than those observed during the first three weeks of lactation.

In this respect, Alves et al. (2003) and Mourão et al. (2004) observed that, the prebiotic additives lead to increase feed efficiency in rabbits, which may lead to increased milk secretion and its yield in treated rabbits. Besides that, the increase in milk production may be due to increase in litter size at birth, where there was a positive correlation between the litter size at birth and milk yield (Lebas et al., 1997 and Rommers et al., 2001). Generally, the improvement in litter traits proved that, the MOS treatment is capable to improve the milking ability of the doe which is reflected in her care and ability to suckle her young till weaning.

Growth rate of pups in the period from 21 days of age until weaning tended to increase with increasing the level of MOS in diet and the best value was obtained with the high dietary MOS level (1.5 g), as compared with control group ( 44.48 vs. $35.42 \%, \mathrm{P}<0.05$, respectively). The improvement in growth performance resulted from the addition of MOS could be due to the selectively stimulates the growth and/or activity of intestinal bacteria associated with health and wellbeing (Gibson, 1999). Furthermore, 


\section{Egyptian J. Nutrition and Feeds (2017)}

the increase in growth performance in treated rabbits may be due to the role of prebiotic oligosaccharides in increasing the concentrations of calcium and magnesium in the colon. Elevated concentrations of these cations in the colon may help to control the rate of cell turnover (Grizard and Barthomeuf, 1999). Prebiotics may have anticarcinogenic, antimicrobial, and glucose-modulatory activities (Hughes and Rowland, 2001). They may also have activity in improving mineral absorption and balance (Grizard and Barthomeuf, 1999 and Roberfroid, 2000).

\section{Relative revenue:}

Data of the growth performance (weight gain of pups in the period from birth until the weaning and feed intake of does during pregnancy and lactation periods) were subjected to economic study according prices of materials and products in Egyptian market at the time of experiment (Table 5). Total feed cost increased by increasing levels of MOS in diets, as a result of improves of feed intake and increase price of feed. However, weaning rabbit produced (kg/ doe) increased by $80.96 \%$ for rabbit does fed $1.5 \mathrm{~g} \mathrm{MOS} / \mathrm{kg}$ diet, as compared with those fed control diet. Also, selling price was increased by increasing dietary MOS level, as a result of increase of weaning rabbit produced $(\mathrm{kg} / \mathrm{doe})$. The same trend was found in the net revenue and economic efficiency, which were increased, as MOS level increased in the diets. The best value of economic efficiency was found in the rabbits fed diet containing $1.5 \mathrm{~g} \mathrm{MOS} / \mathrm{kg}$ diet $(56.45 \%)$, while the poorest value was recorded with those fed control diet $(3.71 \%)$.

\section{CONCLUSIONS}

Supplementing MOS in rabbit does diet significantly improve the overall productive and reproductive performance of rabbits does during pregnancy and lactation periods, in addition to depressing the mortality of pups under high ambient temperature during summer season in Egypt. Therefore, it could be recommended providing rabbit does diet with MOS up to $1.5 \mathrm{~g} / \mathrm{kg}$ diet is advisable in hot climates, Egypt.

\section{REFERENCES}

Abou Khadiga, G.; Youssef, Y. M. K.; Saleh, K.; Nofal, R. Y. and Baselga, M., 2010. Genetic trend in selection for litter weight in two maternal lines of rabbits in Egypt. World Rabbit Sci., 18: 27 - 32.

Alves, A.; Pinheiro, V.; Mourão, J. L.; Oliveira, J.; Gama, A.; Pereira, A.; Eouzan, J.; and Madureira, M., 2003. Effect of diets supplemented with promoters of digestive flora and alimentary tract development on performances and morphometry of ileal mucosa of growing rabbits. COST Action 848. Scientific Meeting Nutrition and Pathology (WG 4) and Meat quality (WG 5), September 25, Prague, Czech Republic, pp. 25.

AOAC, 2000. Association of Official Analytical Chemists. Official Methods of Analysis. 17th Ed. AOAC, Washington, DC, USA.

Ayyat, M. S.; Marai, I. F. M. and El-Sayiad, G. H. A., 1995. Genetic and nongenetic factors affecting milk production and preweaning litter traits of New Zealand White does, under Egyptian conditions. J. World Rabbit Sci. 3, 119-124.

De Blas, J. C. and Mateos, G. G., 1998. Feed Formulation. In: De Blas C., Wiseman J. (Eds). The Nutrition of the Rabbit. CABI Publishing. CAB International, Wallingford Oxon, UK, 241-253.

Duncan, D. B., 1955. Multiple range and multiple F. tests. Biometrics, 11:1-42.

Fairchild, A. S.; Grimes, J. L.; Jones, F. T.; Wineland, M. J.; Edens, F. W.; and Sefton, A. E., 2001. Effects of hen age, Bio-Mos, and Flavomycin on poult susceptibility to oral Escherichia coli challenge. Poultry Sci. 80, 562-571.

Fernandez, F.; Hinton, M.; and Gils, B. V., 2003. Dietary mannan-oligosaccharides and their effect on chickes caecal microflore in relation to salmonella enteritidis colonization. Avian Pathology, 31:49.

Finucane, M.; Spring, P.; and Newman, K. E., 1999. Poster S179, Southern Poultry Science, Jan 18-21, Atlanta.

Forchielli, M. L. and Walker, W. A., 2005. The role of gut-associated lymphoid tissues and mucosal defence. Brit. J. Nutr., 93: 41- 48. 
Fonseca, A. P. 1.; Falcão, L. 1.; Kocher, A.; and Spring, P., 2004. Effects of dietary mannan oligosaccharide in comparison to oxytetracyclin on performance of growing rabbits. $8^{\text {th }}$ World Rabbit Congress, Puebla, Mexic.

Gibson, G. R., 1999. Dietary modulation of the human gut microflora using the prebiotics oligofructose and inulin. Am. Socity Nutr. Sci., 129:1438-1441.

Grizard, D. and Barthomeuf, C., 1999. Non-digestible oligosaccharides used as prebiotic agents: mode of production and beneficial effects on animal and human health. Reprod. Nutr. Dev., 39:563-588.

Habeeb, A.A.M., Aboul-Naga, A.I., Khadr, A.F., 1999. Deterioration effect of summer hot climate on bunnies of acclimatized rabbits during suckling period. In: Proceedings of 1st Interna-tional Conference on Indigenous Versus Acclimatized Rabbits, El-Arish, North Sinai, Egypt, pp. 253263.

Hooge, D., 2004a. Meta-analysis of Broiler Chicken Pen Trials Evaluating Dietary Mannan Oligosaccharide, 1993-2003. Int. J. Poult. Sci. 3: 163-174.

Hooge, D., 2004b. Turkey Pen Trials with Dietary Mannan Oligosaccharide: Meta-analysis, $1993-$ 2003. Int. J. Poult. Sci. 3, 179-188.

Hughes, R. and Rowland, I. R., 2001. Stimulation of apoptosis by two prebiotic chicory fructans in the rat colon. Carcinogenesis, 22:43-47.

Huyghebaert, G., 2003. Replacement of antibiotics in poultry. Eastern Nutrition Conference, Québec, Canada, pp. 55-78.

Kembhavi, A., 2004. Feed additives. In: Biotechnology Application for the Indian Animal Feed Industry: Prospects for Growth. Food and Agriculture Organization of the United Nations, FAO, Rome, Italy.

Lebas, F., 1984. Effect de la simultaneite de la lactation et de la gestation sur les performance laitieres chez la lapine. Annales de Zootechnie, 21: 185-191.

Lebas, F.; Coudert, P.; Rochambeau, H. De. and Thébault, R. G., 1997. The Rabbit Husbandry, Health and Production. Food and Agriculture Organization of the United Nations, FAO, Rome, Italy.

Macfarlane, G. T. and Cummings, J. H., 1999. Probiotics and prebiotics: can regulating the activities of intestinal bacteria benefit health. West. J. Med., 171:187-191.

Marai, I. F. M.; Ayyat, M. S. and Abd El-Monem, U. M., 2001. Growth performance and reproductive traits at first parity of New Zealand white female rabbits as affected by heat stress and its alleviation under Egyptian conditions. Trop. Anim. Health Prod. 33, 451-462.

Marai, I. F. M.; Habeeb, A. A. M. and Gad, A. E., 2002. Rabbits' productive, reproductive and physiological performance traits as affected by heat stress: a review. Livestock Production Science, 78: 71-90.

Mateos, G. G.; Rebollar, P. G. and de Blas, C., 2010. Minerals, Vitamins and Additives. In: The Nutrition of the Rabbit. (Edit. De Blas J.C. and Wiseman J.), $2^{\text {nd }}$ Ed. CABI, Wallingford, pp.119-150.

Miguel, J. C.; Rodrigues-Zas, S. L. and Pettigrew, J. E., 2002. Practical response to Bio-Mos in nursery pigs: a meta-analysis. In 'Nutritional Biotechnology in the Feed and Food Industries'. Lexington, KY. (Eds TP Lyons and K Jacques) pp. 425-433. (Nottingham Press).

Morsy, W. A., 2007. Physiological effects in the digestive tract that result of using nontraditional diets and their relationship with productive and reproductive performance of rabbits. Ph.D. Thesis, Fac. of Agri. Kafr El-Sheikh, Kafrelsheikh University, Egypt.

Morsy, W. A. and Abd El-Lateif, A. I., 2014. Effect of prebiotic supplementation level and method on productive performance of growing rabbits. 7th International Poultry Conference, 3 - 6 November 2014, Ain Sukhna, Red Sea - Egypt. Pp. 14-28.

Mourão, J. L.; Alves, A.; and Pinheiro, V., 2004. Effects of fructo-oligosaccharides on performances of growing rabbits. $8^{\text {th }}$ World Rabbit Congress, Puebla, Mexic.

Newman, K., 1994. Mannan-oligosaccharides: Natural polymers with significant impact on the gastrointestinal microflora and the immune system. In: Biotechnology in the Feed Industry. Lyons, T. P. A. J., K.A. (ed.) Nottingham University Press, Nicholasville, Kentucky, pp. 167-180.

Nour El-Din, A. N. M., 2015. Milk production and some blood metabolite responses to yeast supplementation in early lactating holstein dairy cows. Egyptian J. Anim. Prod., 52 (1):11-17. 


\section{Egyptian J. Nutrition and Feeds (2017)}

Parigi-Bini, R.; Xiccato, G. and Cinetto, M., 1991. Utilization and partition of digestible energy in primiparous rabbit does in different physiological stages. Proc. $12^{\text {th }}$ International Symposium on Energy Metabolism, Zurich, pp. 284-287.

Pinheiro, V.; Alves, A.; Mourão, J. L.; Guedes, C. M.; Pinto, L.; Spring, P. and Kocher, A., 2004. Effect of mannan oligosaccharides on the ileal morphometry and cecal fermentation of growing rabbits. $8^{\text {th }}$ World Rabbit Congress, Publa, Mexic.

Prasad, R. and Karim, S. A., 1998. Effect of dietary energy and protein level on performance and digestibility parameters in pregnant and in lactating rabbit does under tropical environment. World Rabbit Sci., 6: 271-276.

Roberfroid, M. B., 2000. Prebiotics and probiotics: are they functional foods?. Am. J. Clin. Nutr., 71:1682-1687.

Rommers, J. M.; Meijerhof, R.; Noordhuizen, J. P. T. M. and Kemp, B., 2001. Effect of different feeding levels during rearing and age at first insemination on body development, body composition and puberty characteristics of rabbit does. World Rabbit Sci., 9:101-108.

SAS. Institute, 1985. SAS User's Guide : Statistics Version, Fifth Edition. SAS Institute Inc., Cary NC., USA.

Savage, T. F.; Cotter, P. F. and Kakrzewska, E. I., 1996. The effect of feeding mannan oligosaccharide on immunoglobulins, plasma IgG and bile IgA of Wrolstad MW male turkeys. Poult. Sci., 75:143.

Shafie, M. M.; Kamar, G. A. R.; Borady, A. H. A. and Hassanein, M. M., 1984. Reproductive performance of Giza rabbit does under different natural and artificial environmental conditions. Egyptian Journal of Animal Production, 24: 167-174.

Spring, P.; Wenk, C.; Dawson, K. A. and Newman, K. E., 2000. The effects of dietary mannanoligosaccharides on cecal parameters and the concentrations of enteric bacteria in the ceca of Salmonella-challenged broiler chicks. Poult. Sci., 79: 205-211.

White, L. A.; Newman, M. C.; Cromwell, G. L. and Lindemann, M. D., 2002. Brewers dried yeast as a source of mannan oligosaccharides for weanling pigs. J. Anim. Sci., 80:2619-2628.

Xiccato, G., 1996. Nutrition of lactating does. Proc. of $6^{\text {th }}$ World Rabbit Congress, Toulouse, Vol. 1, pp. 29-47. 
تأثير المنان اوليجوسكريد المضاف لعلائق الأرانب على الاداء الاتتاجى والتتاسلى للأمهات خلال فصل الصيف فى

وائل عوض محمود مرسى و عطية ابراهيم عبداللطيف

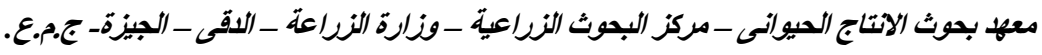

تهدف الدراسة لتحديد تأثير اضافة المنان أوليجوسكريد الى علائق أناث الأرانب على الاداء الانتاجى والتتاسلى وتركيب اللبن تحت

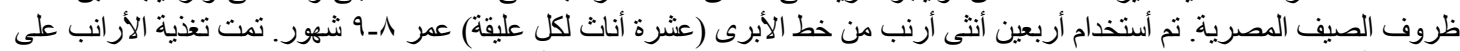

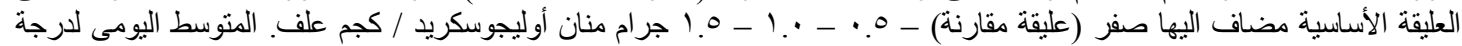

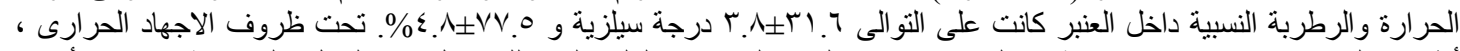

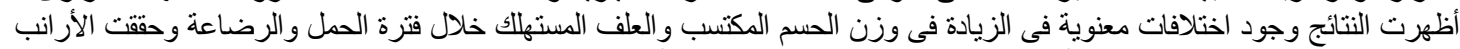

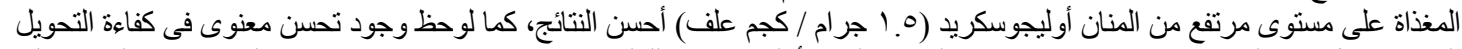

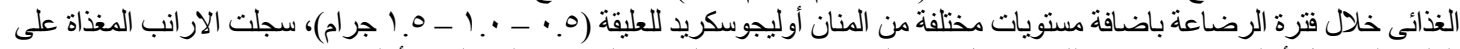

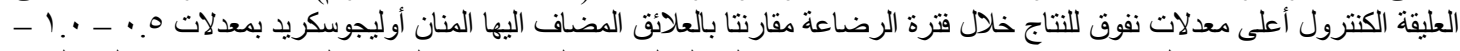

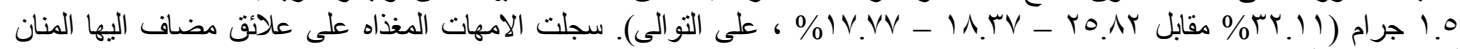

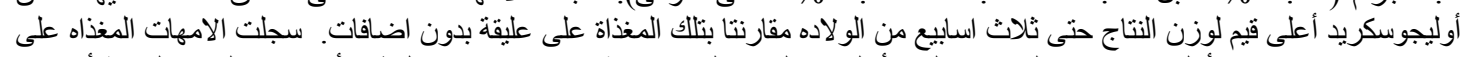

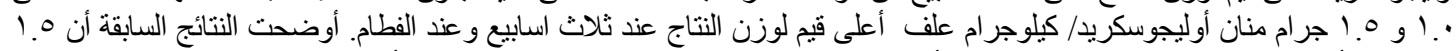

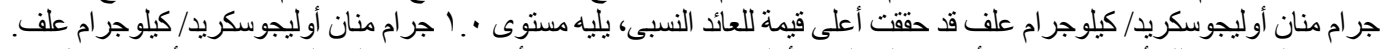

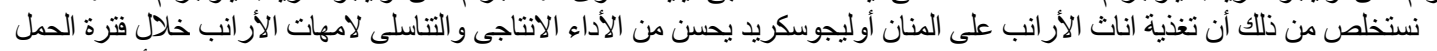

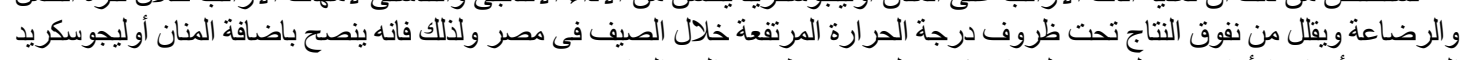

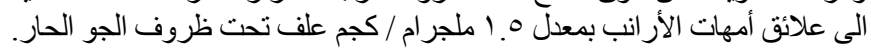


Table (1): Composition and chemical analysis of the basal diet.

\begin{tabular}{|c|c|c|c|}
\hline Ingredient & $\%$ & Chemical analysis (\% as DM): & $\%$ \\
\hline Berseem hay (Trifolium alexandrinum) & 30.05 & Dry matter (DM) & 85.81 \\
\hline Barley grain & 24.60 & Crude protein $(\mathrm{CP})$ & 17.36 \\
\hline Wheat brain & 21.50 & Organic matter $(\mathrm{OM})$ & 91.42 \\
\hline Soybean meal ( $44 \% \mathrm{CP})$ & 17.50 & Crude fiber $(\mathrm{CF})$ & 12.37 \\
\hline Molasses & 3.00 & Ether extract $(\mathrm{EE})$ & 2.229 \\
\hline Limestone & 0.95 & Metabolizable energy (ME, kcal/kg) & 2257 \\
\hline Di-calcium phosphate & 1.60 & Calcium $^{(2)}$ & 1.243 \\
\hline Sodium chloride & 0.30 & Phosphorus $^{(2)}$ & 0.808 \\
\hline Mineral-vitamin premix ${ }^{(1)}$ & 0.30 & Methionine $^{(2)}$ & 0.454 \\
\hline DL-Methionine & 0.20 & Lysine $^{(2)}$ & 0.862 \\
\hline
\end{tabular}

Table (2): Effect of dietary mannan oligoscharides (MOS) supplementation on does performance during gestation and lactation periods of APRI line rabbits.

\begin{tabular}{lcccccr}
\hline \multirow{2}{*}{ Items } & \multicolumn{9}{c}{ MOS levels $(\mathrm{g} / \mathrm{kg}$ diet $)$} & \multirow{2}{*}{ SEM } & P-value \\
\cline { 2 - 5 } & 0 & 0.5 & 1.0 & 1.5 & & \\
Does weight (g) at: & 3024 & 3024 & 3022 & 3022 & 25.51 & 0.9999 \\
Mating & $3340^{\mathrm{c}}$ & $3356^{\mathrm{bc}}$ & $3425^{\mathrm{ab}}$ & $3436^{\mathrm{a}}$ & 26.34 & 0.0316 \\
Pre-Partum & 2993 & 2999 & 3004 & 3022 & 19.73 & 0.8260 \\
Partum & 2882 & 2896 & 2914 & 2935 & 19.13 & 0.3707 \\
Weaning & & & & & & \\
Does weight Gain (g) at: & $316.4^{\mathrm{b}}$ & $331.4^{\mathrm{b}}$ & $402.9^{\mathrm{a}}$ & $414.3^{\mathrm{a}}$ & 15.90 & 0.0001 \\
Gestation & $-110.7^{\mathrm{b}}$ & $-102.9^{\mathrm{b}}$ & $-90.7^{\mathrm{a}}$ & $-87.1^{\mathrm{a}}$ & 3.998 & 0.0009 \\
Lactation & & & & & & \\
Feed intake (g/d) for: & $131.2^{\mathrm{b}}$ & $137.4^{\mathrm{ab}}$ & $146.3^{\mathrm{ab}}$ & $151.3^{\mathrm{a}}$ & 4.304 & 0.0370 \\
Pregnant does & $191.8^{\mathrm{b}}$ & $199.5^{\mathrm{ab}}$ & $211.6^{\mathrm{a}}$ & $216.8^{\mathrm{a}}$ & 6.119 & 0.0373 \\
Lactating does & $94.0^{\mathrm{b}}$ & $157.6^{\mathrm{a}}$ & $167.1^{\mathrm{a}}$ & $171.3^{\mathrm{a}}$ & 4.834 & 0.0001 \\
Pups (22-30 day) & & &
\end{tabular}

$a, b, c$, Means in the same row with different superscripts are significantly different $(P<0.05)$.

$S E M=$ Standard error of means.

Table (3): Effect of dietary mannan oligoscharides (MOS) supplementation on milk production of APRI line rabbits.

\begin{tabular}{|c|c|c|c|c|c|c|}
\hline \multirow{2}{*}{ Items } & \multicolumn{4}{|c|}{ MOS levels (g/kg diet) } & \multirow{2}{*}{ SEM } & \multirow{2}{*}{ P-value } \\
\hline & 0 & 0.5 & 1.0 & 1.5 & & \\
\hline \multicolumn{7}{|l|}{ Milk production $(\mathrm{g} / \mathrm{d})$ at: } \\
\hline $1^{\text {st }}$ week & $70.00^{\mathrm{b}}$ & $75.71^{\mathrm{ab}}$ & $92.14^{\mathrm{a}}$ & $92.86^{\mathrm{a}}$ & 5.861 & 0.0707 \\
\hline $2^{\text {nd }}$ week & $96.43^{\mathrm{c}}$ & $107.5^{\mathrm{bc}}$ & $122.1^{\mathrm{ab}}$ & $127.1^{\mathrm{a}}$ & 6.349 & 0.0057 \\
\hline $3^{\text {rd }}$ week & $144.3^{\mathrm{b}}$ & $158.6^{\mathrm{ab}}$ & $174.9^{\mathrm{a}}$ & $180.1^{\mathrm{a}}$ & 6.764 & 0.0059 \\
\hline $4^{\text {th }}$ week & $72.86^{\mathrm{c}}$ & $85.71^{\mathrm{b}}$ & $100.4^{\mathrm{a}}$ & $108.6^{\mathrm{a}}$ & 4.185 & 0.0001 \\
\hline Milk yield (g/d) & $95.89^{\mathrm{b}}$ & $106.9^{\mathrm{b}}$ & $122.4^{\mathrm{a}}$ & $127.2^{\mathrm{a}}$ & 4.938 & 0.0001 \\
\hline Feed efficiency $(\mathrm{g} / \mathrm{g})^{(1)}$ & $0.500^{\mathrm{b}}$ & $0.536^{\mathrm{b}}$ & $0.577^{\mathrm{a}}$ & $0.588^{\mathrm{a}}$ & 0.011 & 0.0002 \\
\hline
\end{tabular}

$a, b, c$, Means in the same row with different superscripts are significantly different $(P<0.05)$.

$S E M=$ Standard error of means.

(1) Milk yield ( $g$ )/does feed intake ( $g$ ) 
Table 4: Effect of dietary mannan oligoscharides (MOS) supplementation on letter performance of APRI line rabbits.

\begin{tabular}{|c|c|c|c|c|c|c|}
\hline \multirow{2}{*}{ Items } & \multicolumn{4}{|c|}{ MOS levels (g/kg diet) } & \multirow{2}{*}{ SEM } & \multirow{2}{*}{ P-value } \\
\hline & 0 & 0.5 & 1.0 & 1.5 & & \\
\hline \multicolumn{7}{|l|}{ Litter size at: } \\
\hline Birth (alive) & 6.14 & 6.57 & 7.14 & 7.14 & 0.340 & 0.1176 \\
\hline 21 days & $5.00^{\mathrm{b}}$ & $5.43^{\mathrm{ab}}$ & $6.14^{\mathrm{a}}$ & $6.29^{\mathrm{a}}$ & 0.369 & 0.0463 \\
\hline Weaning (30day) & $4.14^{\mathrm{b}}$ & $4.86^{\mathrm{b}}$ & $5.86^{\mathrm{a}}$ & $5.86^{\mathrm{a}}$ & 0.261 & 0.0010 \\
\hline \multicolumn{7}{|l|}{ Mortality rate $(\%)$ at: } \\
\hline Birth - 21 day & 18.50 & 17.57 & 13.95 & 12.42 & 2.046 & 0.1997 \\
\hline Birth - Weaning & $32.11^{\mathrm{a}}$ & $25.82^{\mathrm{ab}}$ & $18.37^{\mathrm{b}}$ & $17.77^{\mathrm{b}}$ & 2.585 & 0.0052 \\
\hline \multicolumn{7}{|l|}{ Litter weight (g) at: } \\
\hline Initial & $293.6^{\mathrm{b}}$ & $323.6^{\mathrm{b}}$ & $387.1^{\mathrm{a}}$ & $401.4^{\mathrm{a}}$ & 15.57 & 0.0004 \\
\hline $7^{\text {th }}$ day & $562.1^{\mathrm{b}}$ & $680.7^{\mathrm{b}}$ & $821.4^{\mathrm{a}}$ & $870.0^{\mathrm{a}}$ & 36.93 & 0.0001 \\
\hline $14^{\text {th }}$ day & $785.7^{\mathrm{c}}$ & $996.4^{\mathrm{b}}$ & $1237.1^{\mathrm{a}}$ & $1260.0^{\mathrm{a}}$ & 30.25 & 0.0001 \\
\hline $21^{\text {st }}$ day & $1011.4^{\mathrm{c}}$ & $1328.6^{\mathrm{b}}$ & $1616.4^{\mathrm{a}}$ & $1652.1^{\mathrm{a}}$ & 49.84 & 0.0001 \\
\hline Weaning (30 day) & $1444.3^{c}$ & $1892.9^{\mathrm{b}}$ & $2494.3^{\mathrm{a}}$ & $2612.9^{\mathrm{a}}$ & 77.67 & 0.0001 \\
\hline Kit weight at birth (g) & $47.87^{\mathrm{c}}$ & $49.65^{\mathrm{bc}}$ & $54.35^{\mathrm{ab}}$ & $56.33^{\mathrm{a}}$ & 1.718 & 0.0066 \\
\hline Kit weight at weaning (g) & $349.50^{c}$ & $392.2^{\mathrm{b}}$ & $433.8^{\mathrm{a}}$ & $446.5^{\mathrm{a}}$ & 10.91 & 0.0001 \\
\hline $\begin{array}{l}\text { Growth Rate of Pups (\%) (21day- } \\
\text { weaning) }\end{array}$ & $35.42^{\mathrm{b}}$ & $34.90^{\mathrm{b}}$ & $42.64^{\mathrm{ab}}$ & $44.48^{\mathrm{a}}$ & 2.170 & 0.0506 \\
\hline Milk Index ${ }^{(1)}$ & $3.370^{\mathrm{b}}$ & $3.603^{\mathrm{a}}$ & $3.621^{\mathrm{a}}$ & $3.606^{\mathrm{a}}$ & 0.036 & 0.0030 \\
\hline \multicolumn{7}{|l|}{ Feed conversion rate $(\mathrm{g} / \mathrm{g})$ : } \\
\hline 1 to 21 days of lactation ${ }^{(2)}$ & $5.708^{\mathrm{a}}$ & $4.185^{\mathrm{b}}$ & $3.648^{\mathrm{b}}$ & $3.644^{\mathrm{b}}$ & 0.157 & 0.0001 \\
\hline 22 to 30 days of lactation ${ }^{(3)}$ & $6.054^{\mathrm{a}}$ & $6.121^{\mathrm{a}}$ & $3.940^{\mathrm{b}}$ & $3.959^{\mathrm{b}}$ & 0.355 & 0.0028 \\
\hline
\end{tabular}

$a, b, c$, Means in the same row with different superscripts are significantly different $(P<0.05)$.

$S E M=$ Standard error of means.

(1) As [(Litter weight ( $g$ ) at 21 days after birth - Litter weight ( $g$ ) at 24 hours after birth)/ (21 X Litter weight $(g)$ at 21 days after birth)] X 100 (Calculated according to Niedzwiadek, 1981).

(2) As feed intake of does from 1 to 21 days $(\mathrm{g})$ per litter weight gain from 1 to 21 days $(\mathrm{g})$.

(3) As feed intake of does from 22 to 30 days ( $g$ ) per litters weight gain from 22 to 30 days $(\mathrm{g})$.

Table (5): Effect of dietary mannan oligoscharides (MOS) supplementation on relative revenue of rabbit does.

\begin{tabular}{lcccc}
\hline \multirow{2}{*}{ Items } & \multicolumn{4}{c}{ MOS levels (g/kg diet) } \\
\cline { 2 - 5 } & 0 & 0.5 & 1.0 & 1.5 \\
\hline Total feed intake (kg) $)^{(1)}$ & 10.536 & 11.526 & 12.239 & 12.584 \\
Price /kg diet (L.E.) & 3.304 & 3.314 & 3.324 & 3.334 \\
Total feed cost (L.E.) & 34.81 & 38.19 & 40.68 & 41.95 \\
Weaning rabbit produced (kg/ doe) $_{\text {Selling price (L.E.) }}^{(2)}$ & 1.444 & 1.893 & 2.494 & 2.613 \\
Net revenue (L.E.) $^{(3)}$ & 36.11 & 47.32 & 62.36 & 65.32 \\
Economic efficiency (\%) $^{(4)}$ & 1.29 & 9.13 & 21.68 & 23.68 \\
\hline
\end{tabular}

- Other conditions like mortality (\%) and management are fixed.

- Ingredients price (L.E. per ton) at 2016 were: 3500 barley; 1600 berseem hay; 2900 wheat bran; 6000 soybean meal (44\%) ; 2000 molasses ; 25 limestone ; 9000 premix ; 40000 methionine ; 1000 di-calcium phosphate; 1000 salt; 20000 Bio-MOS.

- Adding 100 L.E. Iton for pelliting.

(1) Total feed intake $=($ Pregnant does daily feed intake X 30) $+($ Lactating does daily feed intake X 30) $+($ Pups daily feed intake $X$ 9)

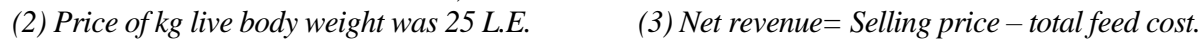

(4) Economic efficiency $=(\text { Net revenuel total feed cost })^{*} 100$ 